Special Issue of the 7th International Advances in Applied Physics and Materials Science (APMAS 2017)

\title{
Microbial Ability to Colonize Mural Painting and Its Substrate
}

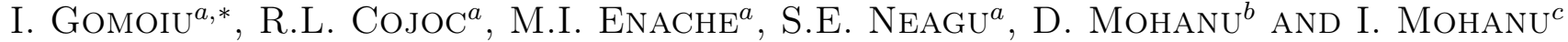 \\ ${ }^{a}$ Microbiology Department, Institute of Biology Bucharest, Romanian Academy, \\ 296, Spl Independentei, 060031, Bucharest, Romania \\ ${ }^{b}$ Conservation and Restoration Department, National University of Arts,
}

19, G. Budişteanu, 010773, Bucharest, Romania

${ }^{c}$ Binders Materials Research Department, CEPROCIM S.A., 6 Blvd Preciziei, 10146, Bucharest, Romania

The aim of the present work is to point out the role of microorganisms in biodeterioration from two different historical monuments located in Romania: the refectory of the Hurezi monastic complex and Amărăşti church. Mural painting was made in al frescoes technique applied on the brick or on the wooden poles. HOBO LCD data loggers revealed values of temperature between 5 and $24^{\circ} \mathrm{C}$ and relative humidity between 60 and $90 \%$ which are favorable for the colonization by bacteria and fungi. Two different genera of moderately halophilic bacteria (Nesterenkonia and Halobacillus) and 5 different genera of fungi (Antrodia, Aspergillus, Alternaria, Penicillium and Ulocladium) had been identified either by molecular techniques or by cultural and mycelium characteristics. They developed a pink and black pigmentation. The main vehicles for spreading of microorganisms are as follows: insects, condensation, convection currents and human activity. Bacterial cells and mycelia have been found both on the surface of the mural paintings, mortars, wooden structure as well as in the fissures and pores. Bacteria producing carotenoids grow on the surface of the substrates but fungi can be located both on the substrate and under it developing in the same time aerial and substrate hyphae. Mycelia produce the peeling and loosing of the pictorial layer. Organic acids act as chelating agents and mycelium as pulling agent. The aesthetical and structural changes of mural painting can be prevented by monitoring the environment and avoiding contamination. If damages took place, understanding their origin and proper treatment will contribute to preserving of cultural heritage.

DOI: 10.12693/APhysPolA.134.383

PACS/topics: mural painting, wooden church, environmental parameters, deterioration index, microbial colonization, biodeterioration

\section{Introduction}

The colonization of mural painting by microorganisms has as consequence the biodeterioration which leads to aesthetical and structural changes. The availability of nutrients, water permeability, chemical composition of materials and porosity has a great impact on the intensity of biodeterioration [1]. The macroscopic symptoms of biodeterioration are: altered structure, fiber splitting, pitting, microbial colonization, discoloration, bulging plaster, and peeling pictorial layer [2]. Heterotrophic bacteria and fungi are able to colonize both mural painting and its support represented by bricks or wood. The colonization is supported by chemical composition of the mural paintings, environmental conditions and previous restorations [3]. Most of the microorganisms are common soil inhabitants but they develop specific biota depending on organic compounds, temperature, humidity fluctuation, convection currents, and previous colonizers [4]. The pink discoloration with bacterial origin was identified on wall paintings, buildings, and burial-related material from monuments in central

\footnotetext{
*corresponding author; e-mail: gomoiu@hotmail.com
}

and southern Europe [5-7]. Even if on the surface of the mural painting many species of bacteria and fungi can be found, only those able to colonize them are considered as biodeteriogens. The first colonizers are strongly connected with the initial chemical composition of the art work and environmental conditions. The following colonizers are depending on the chemical changes in the substrate produced by previous species, their debris, and current environmental conditions.

In this study we investigated the ability of microorganisms to colonize the mural painting and its support and to produce aesthetical and structural changes in two Romanian historical monuments with different architecture. Pink and black pigmented areas, peeling and losing of the pictorial layer have been found. We also put in evidence the ability of fungi to grow on the surface already colonized by bacteria producing carotenoids.

\section{Material and methods}

Microclimate monitoring was performed using HOBO LCD data loggers for temperature and relative humidity $(\mathrm{RH})$ placed in different areas and heights. In the refectory of the Hurezi monastic complex, the data loggers have been placed on the southern and northern wall at the height of $2.75 \mathrm{~m}$. The refectory communicated with 
the outside through the door which was open during the day. In the Amărăşti church, data loggers were fixed in the pre nave on the northern and on the southern wall at the height of $1.7 \mathrm{~m}$ respectively of $2.5 \mathrm{~m}$, in the nave on the northern wall at the height of $1.7 \mathrm{~m}$ and in the altar, on the eastern wall, at the height of $1.8 \mathrm{~m}$. All parts of the Amărăşti church communicated with the outside through blanks arising from the loss of plaster, timber and windows.

Visual inspection allowed identifying the colonization of pictorial layer, plaster and bricks (if visible) in the refectory and the colonization of pictorial layer, plaster and wood (if visible) in case of Amărăşti church.

The index of deterioration (DI) was calculated using the formula proposed by Piotrowska et al. [2]. The northern, southern, eastern, and western walls in the refectory and the porch, pre-nave, nave, and altar walls of Amărăşti church were evaluated over a period of two years (2014-2015).

The walls of the refectory and Amărăşti church were sampled at $60 \mathrm{~cm}$ above the ground and observed under scanning electron microscope (SEM; JEOL JSPM 5200, Japan) to identify the presence of microorganisms and the state of colonization. Also, the contaminated surfaces from the refectory, were sampled by swabbing $10 \mathrm{~cm}^{2}$ areas. A total number of 6 samples were taken from lower part of eastern wall (named R1 and R2), northern wall (named R3 and R4), and western wall (named R5 and R6). Decimal dilutions had been inoculated on solid media supplemented with $10 \%$, respectively $20 \%$ $\mathrm{NaCl}[8]$ as well as on the yeast-glucose-chloramphenicolagar [9] and incubated at $28^{\circ} \mathrm{C}$ for 35 days. Colony forming units (CFU) were counted. Pure cultures have been used to extract DNA either by the procedure described by Tamaoka [10] or using an extraction kit, following the protocol described by the manufacturer (Qiagen). The resulted samples were analyzed for content and purity by UV-VIS spectrophotometer (Thermo Scientific NanoDrop 2000). Subsequently, the DNA was amplified by PCR, cloned and sequenced by commercial company Macrogen following their own protocols and using primers M13F and M13R.

The contaminated surfaces from the altar of Amărăşti church were sampled by swabbing $10 \mathrm{~cm}^{2}$ areas (A1A6), by cutting a small fragment of wood (A7) or by detaching drops of wax coming from burning candle (A8). The samples were weighed (g) and the decimal dilutions were inoculated on yeast glucose chloramphenicol (YGC) substrate medium. CFU were counted. The main filamentous fungi genera were identified to genus level using macroscopic and microscopic colonies characteristics $[11,12]$.

\section{Results and discussions}

The refectory of the Hurezi monastery was built and decorated in the beginning of the eighteenth century. The mural painting was made in al fresco technique. After successive lime washes applied on the mural painting, last restoration performed in 1970 covered lacunas placed in the lower parts of the walls with infilling mortar. The wooden church from Amărăşti, was built in the same century on oak pillars and beams. Mural painting made in al fresco technique dating from XIX century still exists only in the altar.

Microclimate monitoring is presented in Table I in terms of the minimum and maximum values of temperature and $\mathrm{RH}$.

TABLE I

Microclimate parameters in the refectory and Amărăşti church

\begin{tabular}{l|c|c|c|c}
\hline \hline $\begin{array}{c}\text { Microclimate } \\
\text { parameter: }\end{array}$ & \multicolumn{2}{|c|}{$\begin{array}{c}\text { The refectory, } \\
\text { Hurezi complex }\end{array}$} & \multicolumn{2}{c}{$\begin{array}{c}\text { Amărăşti } \\
\text { church }\end{array}$} \\
\cline { 2 - 5 }$T\left[{ }^{\circ} \mathrm{C}\right]$, RH [\%] & Min value & Max value & Min value & Max value \\
\hline$T$ winter & 2.03 & 8.23 & -14.1 & 16.8 \\
RH winter & 24 & 39 & 27.1 & 89.9 \\
$T$ spring & 4.15 & 18.28 & 0 & 21.7 \\
RH spring & 35 & 95 & 23.4 & 76.8 \\
$T$ summer & 15.62 & 24.79 & 13.3 & 31.9 \\
RH summer & 37 & 82 & 23.4 & 73.6 \\
$T$ autumn & 7.83 & 24.1 & -1.1 & 29.9 \\
RH autumn & 35 & 85 & 23.5 & 84.3
\end{tabular}

Visual inspection showed in the refectory the following changes: diffuse and heavy pink biofilm on the frescoes (Fig. 1a), original (Fig. 1b) and infilling mortar (Fig. 1c,d), pink and white efflorescences with detachment of the superficial layer (Fig. 1c), heavy discoloration, diffuse and light discoloration (Fig. 1a).
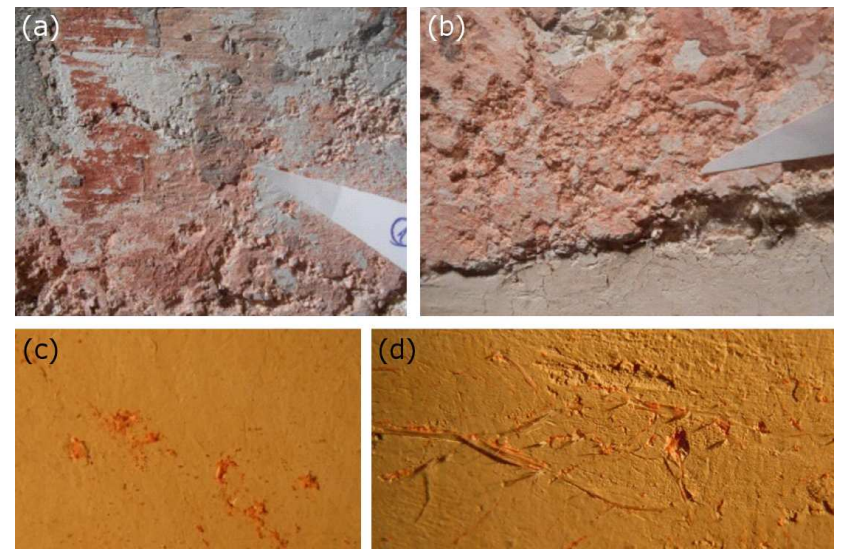

Fig. 1. Diffuse and heavy pink biofilm in the refectory of Hurezi monastic complex: (a) on the frescoes, (b) original mortar, and (c,d) an infilling mortar.

The following types of biodeterioration have been found on the remaining mural painting from Amărăşti church: heavy discoloration, diffuse and light discoloration (Fig. 2a) and brown spots (Fig. 2b,c). On the beams, both in the pre nave and nave, brown cuboid shapes of wood and fruiting bodies have been noticed (Fig. 2d). 

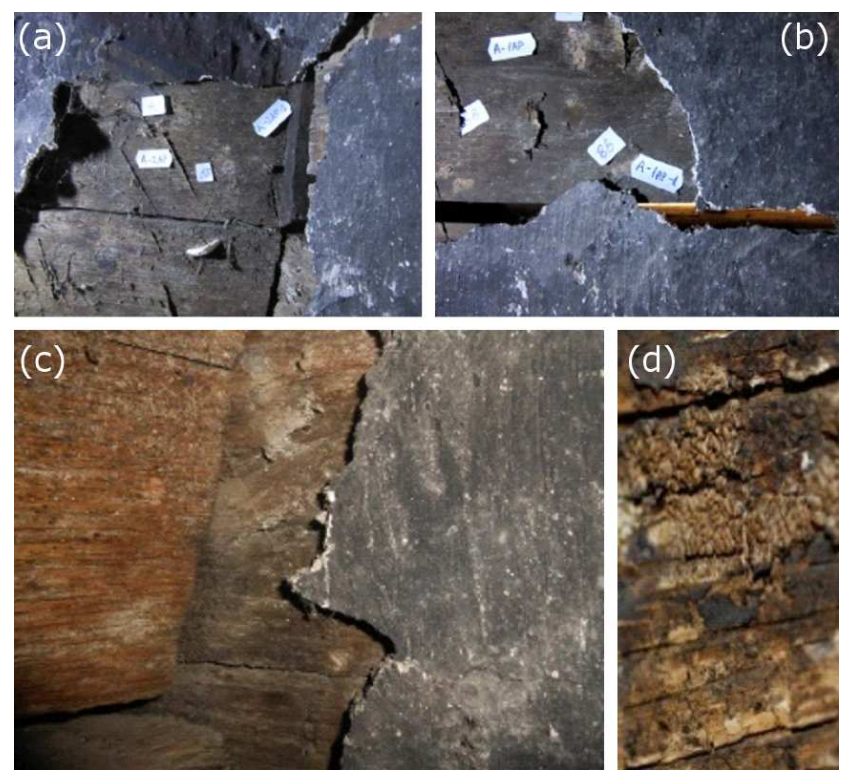

Fig. 2. Heavy discoloration on the mural painting and wooden support of Amărăşti church: $(\mathrm{a}, \mathrm{b})$ the northern wall, (c) the western wall, (d) eastern wall.

\subsection{Deterioration index}

The highest deterioration index has been found in the refectory of the Hurezi monastery (0.75), it being reflected in aesthetical and local structural damages produced by microorganisms, chemical and physical factors. More than $20 \%$ of frescoes were lost. The building had no structural damages and its state of conservation could be improved after the restoration.

The deterioration index for Amărăşti church is lower (0.5) than in the refectory. More than $75 \%$ of fresco was lost and the building presents structural damages due to biodeterioration of the wooden structure and physical factors.

We consider that, in order to express the realistic state of conservation, the value of the deterioration index has to be taken in account in correlation with structural damages.

\subsection{Microscopy analysis}

All stages from the biological cycle of biodetriogens had been found by scanning electron microscopy. They were strongly correlated with the biology of species, available nutrients and environmental conditions. At the Amărăşti church, we found round shaped bacteria isolated or forming groups of 5-10 cells (Fig. 3a) but at the refectory we noticed large groups of round shaped bacteria producing exopolysaccharides and pink biofilm (Fig. 3b). Fragmented dried mycelia (Fig. 4a) germinated spore and (Fig. 4b) mycelium with many and branched hyphae (Fig. 4c) were observed on frescoes of the Amărăşti church. This type of analysis showed that once the spread of microorganisms took place inside the monuments, they could remain in latent stage if environmental conditions are unfavorable or develop all stages from their biological cycle finalizing with the colonization of mural painting, mortar and wood.
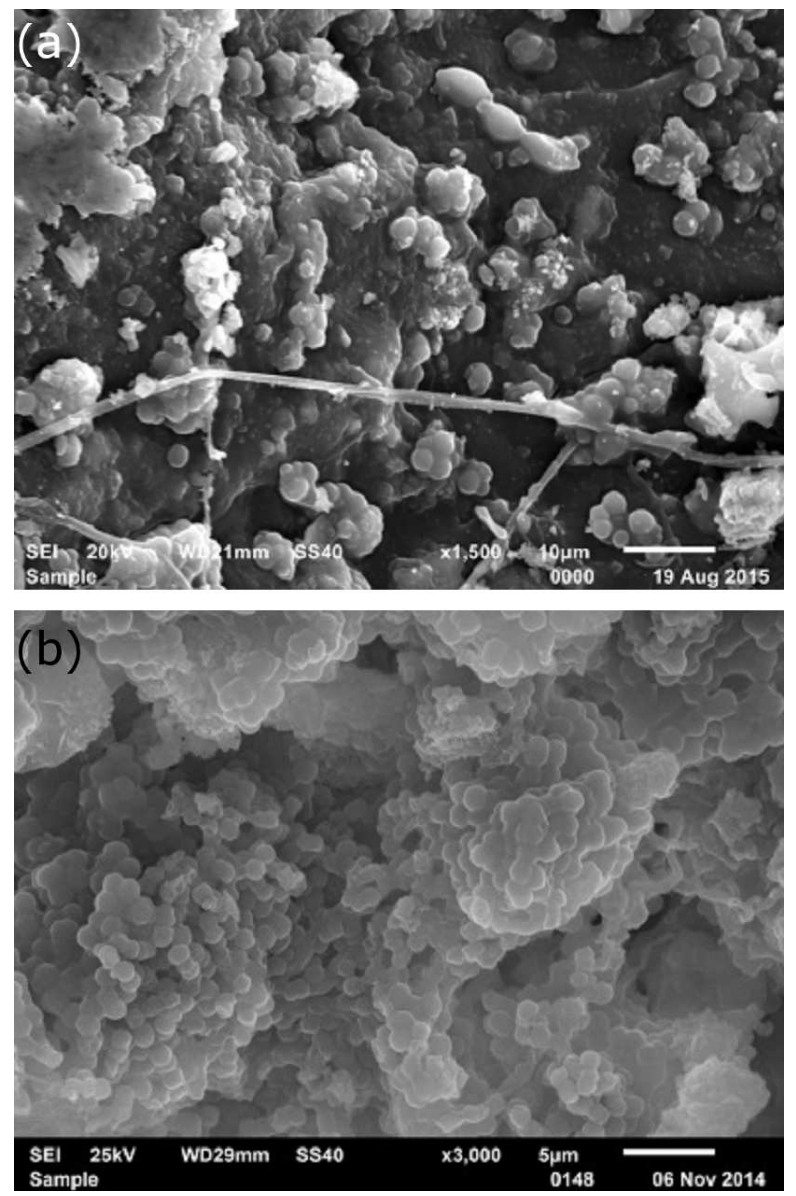

Fig. 3. SEM images of bacteria: (a) small groups, (b) biofilm.

\subsection{Microbiological analysis}

Total amount of microorganisms is correlated with nutrients, available water and environmental conditions. Minimum values of temperature and RH stopped multiplication of microorganisms and the rate of colonization. Opposite, the maximum values of temperature and $\mathrm{RH}$ do not inhibit multiplication and rate of colonization, because they correspond with the species biological needs. Variation of temperature and $\mathrm{RH}$ stimulate or inhibit the rate of colonization. The infilling mortar samples (R1R6) contained $1.0 \times 10^{6}-1.2 \times 10^{8}$ bacterial UFC $/ 10 \mathrm{~cm}^{2}$. The pictorial layer and the drop of wax sampled from the Amărăşti church contained $1.0 \times 10^{2}-1.2 \times 10^{3}$ bacterial $\mathrm{UFC} / 10 \mathrm{~cm}^{2}, 1.1 \times 10^{5}-1.5 \times 10^{6}$ fungal UFC $/ 10 \mathrm{~cm}^{2}$ and fruiting bodies of Antrodia sinuosa. Two different bacterial genera as Nesterenkonia and Halobacillus and four fungal genera as Aspergillus, Alternaria, Penicillium and Ulocladium had been identified. 

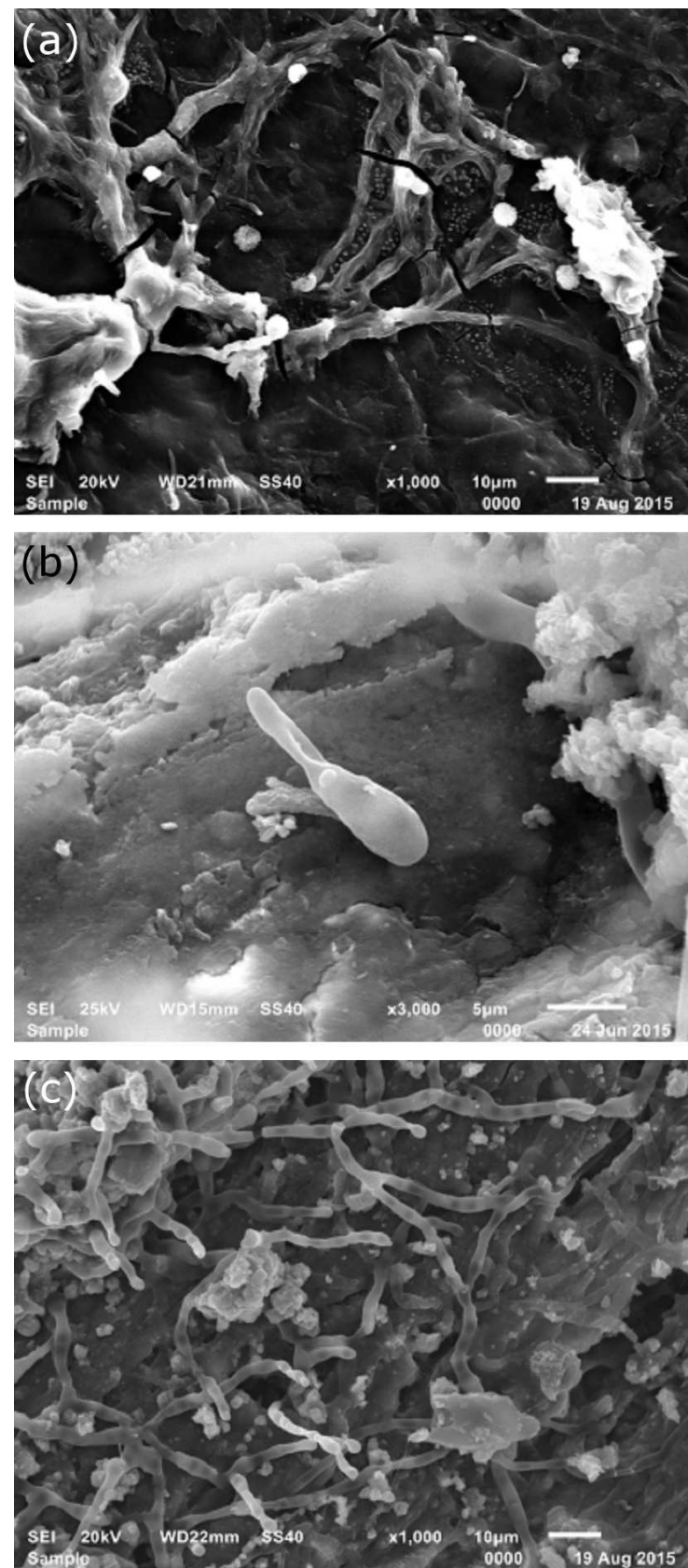

Fig. 4. SEM images of fungi: (a) fragmented and dried mycelia, (b) germinated spore, (c) fluffy mycelium.

\section{Conclusions}

The environmental conditions and available nutrients from the refectory of the Hurezi monastic complex and the Amărăşti church were favorable for colonization of mural painting, mortars, and wooden structure.

Cells multiplication occurred only when the environmental conditions were favorable and consequently the rate of colonization had different values.
Under dry conditions, the bacterial biofilm lost water content; part of it was detached contributing to the spread of cells and becoming a promoter of a new colonization in the other areas; the remaining part had a protective role for the rest of the cells that will become new colonization promoters on the original/initial site. Under the same conditions, fungal spores remain viable and germinate when the substrate becomes wet. If there is not enough water, germinated spores will not be able to develop mycelia and colonization will be prevented. Wet substrate was favorable for the growth of mycelia and for its sporulation.

\section{Acknowledgments}

This research was carried out with financial support of the National Research Program - PN II, MEN - UEFISCDI, project no. PN-II-PT-PCCA-2013-4-0660 and PN-II-PT-PCCA-2013-4-1311.

\section{References}

[1] T.K. Dakal, S.S. Cameotra, Environ. Sci. Eur. 24, 36 (2012).

[2] M. Piotrowska, A. Otlewska, K. Rajkowska, A. Koziróg, M. Hachułka, P. Nowicka-Krawczyk, G.J. Wolski, B. Gutarowska, A. Kunicka-Styczyńska, A. Zydzik-Białek, PLoS ONE 9, e109402 (2016).

[3] O. Pepe, L. Sannino, S. Palomba, M. Anastasio, G. Blaiotta, F. Villani, G. Moschetti, Microbiol. Res. 165, 21 (2010).

[4] V. Raimondi, L. Palombi, D. Longoli, G. Cecchi, I. Gomoiu, in: Laser in the Conservation of Artworks, Eds. M. Castillejo, J. Ruiz, R. Radvan, M. Oujja, Taylor \& Francis Group, London 2008, p. 157.

[5] G. Piñar, J. Ettenauer, K. Sterflinger, in: The Conservation of Subterranean Cultural Heritage, Ed. C. Saiz-Jimenez, Taylor \& Francis Group, London 2014, p. 113.

[6] G. Piñar, D. Piombino-Mascali, F. Maixner, A. Zink, K. Sterflinger, FEMS Microbiol. Ecol. 86, 341 (2013).

[7] L. Laiz, A.Z. Miller, V. Jurado, E. Akatova, S. Sanchez-Moral, J.M. Gonzalez, A. Dionísio, M.F. Macedo, C. Saiz-Jimenez, Naturwissenschaften 96, 71 (2009)

[8] A. Ventosa, M.C. Gutierrez, M.T. García, F. RuizBerraquero, Int. J. Syst. Bacteriol. 39, 382 (1989).

[9] I. Gomoiu, E. Chatzitheodoridis, S. Vadrucci, I. Walther, PLoS ONE 8, e62130 (2013).

[10] J. Tamaoka, in: Chemical Methods in Prokaryotic Systematics, Eds. M. Goodfellow, A.G. O'Donnell, Wiley, Chichester 1994, p. 463.

[11] G.C. Ainsworth, F.K. Sparrow, A.S. Sussman, The Fungi: An Advanced Treatise, Academic Press, New York 1973.

[12] C.J. Alexopoulos, C.W. Mims, M. Blackwell, Introduct. Mycol., 4th ed., Wiley, New York 1996. 